
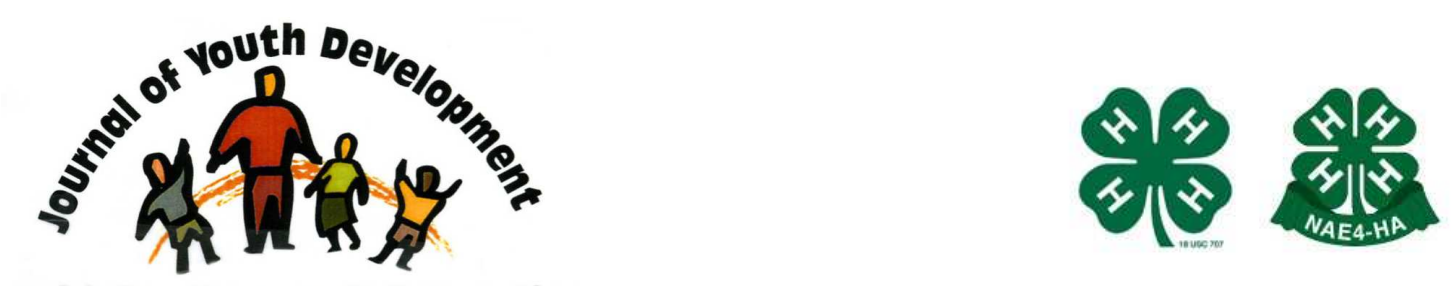

Bridging Research \& Practice

\title{
Positive Youth Development through Civic Engagement
}

\author{
Jennifer S. Parker \\ University of South Carolina Upstate \\ Spartanburg, SC \\ jparker@uscupstate.edu \\ Laura Bauknight \\ Spartanburg Youth Council \\ Spartanburg, SC
}




\title{
JOURNAL OF YOUTH DEVELOPMENT \\ bridging research and practice

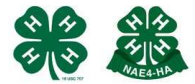

Volume 4, Number 3, Fall 2009

Article 090403PA001

\section{Positive Youth Development through Civic Engagement}

\author{
Jennifer S. Parker \\ University of South Carolina Upstate \\ Laura Bauknight \\ Formerly of Spartanburg Youth Council
}

\begin{abstract}
As part of the 175th anniversary celebration of Spartanburg, South Carolina, three local foundations and the United Way agreed to fund a youth leadership project. A University of South Carolina Upstate (USC Upstate) faculty member with expertise in youth development and the coordinator of the Spartanburg Youth Council agreed to develop the project and serve as the project directors. We developed a youth philanthropy project with expected outcomes of positive development, increased awareness of community issues, and greater civic engagement for the youth. A group of eighteen teens participated in the yearlong project. Interactive workshops on topics such as community goals, grant writing, writing the request for proposals and reviewing grants were conducted. At the culmination of the project, the young philanthropists awarded grants totaling $\$ 12,000$ to eight youth serving organizations. The teens reported many positive developmental experiences and greater awareness of community needs and increased responsibility to their community.
\end{abstract}

\section{Introduction}

Prior research in youth development has focused more on risky behavior of youth and costs of these risks to the individual and to society (Biglan, Brennan, Foster, \& Holder, 2004) but in recent years, some social theorists have begun to view youth as community assets and focus on youth engagement in the community (Watts \& Flanagan, 2007). This approach focuses on development of skills that aid in identifying, analyzing and acting on issues relevant to youth. In this model, adults do not necessarily assume the lead in organized youth activities; instead, they facilitate opportunities to lead and mentor youth (Watts \& Flanagan, 2007). 
For over a half-century theorists have found that active involvement of youth in community affairs strongly correlates to citizenship in adulthood (Mannheim, 1952), and also fosters a sense of belonging and an awareness of being part of a community (Evans \& Prilleltensky, 2007; Flanagan, 2003). In addition, programs that engage youth in the community not only contribute to a thriving community, but also to the development of that young person (Dworkin, Larson \& Hansen, 2003; Harré, 2007; Yates \& Youniss, 1996).

Recent research has begun to look at the developmental outcomes of various types of youth activities. Larson (2000) analyzed positive youth development across several contexts. He specifically focused on the development of initiative, which requires intrinsic motivation, engagement in the environment, and effort directed toward a goal. Initiative is necessary for positive developmental experiences such as leadership and civic engagement. Larson reported that organized voluntary youth activities provided a more fertile context for the development of these skills when compared to school experience and social experience with friends. Therefore, organized, voluntary youth activities may be especially suited for the development of initiative and consequently other positive developmental experiences.

Hansen, Reed and Dworkin (2003) investigated the types of developmental experiences related to five categories of youth activities. These authors utilized the Youth Experiences Survey (YES) (Hansen \& Larsen, 2002) to assess the impact of youth activities. They found higher rates of learning experiences reported in youth activities when compared to time in school or time spent hanging out with friends. Youth who participated in service activities reported high rates of personal development in the area of emotional control, identity exploration and identity reflection when compared to youth involvement in academic activities, sports, or performance and fine arts. The youth in service learning activities also reported higher rates of development in the areas of leadership, prosocial norms, community engagement and family integration.

Another positive benefit of structured youth activities is the formation of positive relations between youth and community adults. Jarrett, Sullivan, and Watkins (2005) found that these relationships provide important social capital for youth and support the transitions to adulthood roles such as going to college, exploring careers and obtaining jobs. These authors also found that the relationships that youth formed with community adults developed in stages, and began initially with wariness, then moved to interaction around a common goal such as a charitable cause. Through the interactions the youth began to perceive the adults as someone who cared about them, which in turn led to meaningful connections.

Libby, Rosen and Sedonaen (2005) explored the practices of a youth leadership organization that engaged youth-adult partnerships (Y-APs) in philanthropy. They found that youth philanthropy, defined as young people giving time and money for social good, strengthened the youth's involvement in the community and built strong relationships with adults. The program paired youth with adults from local foundations to make grant decisions, which resulted in greater youth involvement in the community and advances in personal and interpersonal development. This model was utilized in the present study with a group of youth in Spartanburg, SC.

\section{Purpose}

During 2006, the City of Spartanburg, SC celebrated 175 years of history. Representatives of the City proposed a special activity focusing on youth development to three large foundations in Spartanburg and the United Way of the Piedmont: 
- Spartanburg County Foundation,

- Mary Black Foundation,

- Spartanburg Regional Healthcare Foundation, and

- United Way.

These joint funders agreed to provide support for the youth project and approached the Spartanburg Youth Council and USC Upstate for leadership with this initiative. The group agreed to launch a youth philanthropy project to promote positive development, raise awareness of community issues and increase potential for civic engagement of the youth in Spartanburg. Each funder agreed to support the project with $\$ 2000$, as long as the youth raised a $50 \%$ match. The funders also committed their expertise in fundraising and grant development, as well as volunteering to educate the youth on the Community Indicators Project. Community Indicators is a community assessment, planning and improvement initiative sponsored by the Spartanburg County Foundation, United Way of the Piedmont, Spartanburg County, and USC Upstate. The Community Indicator's Project contains ten goals focused on improving the quality of life for citizens of Spartanburg. The youth participated in a workshop to learn about the goals and selected Goal \#1- Our children and youth will excel academically to be the focus of their philanthropy.

\section{Participants}

A USC Upstate faculty member with expertise in youth development and the coordinator of the Spartanburg Youth Council, agreed to be the project directors. The participants in the philanthropy project were members of Youth Voices, a group of teens that comprise the youth members of the Spartanburg Youth Council. With 30 members, Youth Voices includes diverse youth from all seven Spartanburg school districts and one private school. This was the first opportunity for many of them to be involved in a leadership program. Eighteen of these youth (10 females and 8 males) participated in the yearlong project, while the remaining 12 were not able to participate due to conflicting schedules. Thirteen of the participants were African American, four were Caucasian and one Hispanic. They ranged from 13 to 17 years of age.

\section{Process}

The project was introduced with an interactive activity to define and demonstrate the concept of philanthropy. The youth were informed of the opportunity and invited to participate in the project as philanthropists. At the next meeting a speaker from The United Way conducted a workshop on a community improvement plan, Strategic Spartanburg: Community Indicators project. The United Way facilitator reviewed the ten community improvement goals proposed in the Community Indicator's Project and surveyed potential ways that youth could support these goals. Following the presentation, the youth were encouraged to select one of the community improvement goals to focus on for their philanthropy project. First the youth individually voted and narrowed the choices to three. More discussion followed that focused on those three goals, and another vote brought the group to consensus on one goal. They selected Goal 1: Our children and youth will excel academically to be the focus of the philanthropy project.

An educator and recipient of grant funding for program support presented the next workshop. She spoke to the group and led a discussion on types of educational programs and opportunities for grant funds to help children and youth excel academically. 
Following the introductory activities, the youth participated in a five-day leadership experience sponsored by a Community Outreach Partnership Center Grant awarded to USC Upstate. The purpose of this activity was to develop the teen's leadership skills to enhance the success of the group project. Activities included decision-making, team building and understanding diversity. The week began with two half-day sessions at USC Upstate followed by a full three-day retreat at Haley's Farm in Clinton, Tennessee, which is the home of the Children's Defense Fund. At this retreat the youth participated in an open forum discussion with a panel of young adult philanthropists and continued their leadership development activities. Following the retreat, the youth met one or two times each month to work on the project. A series of workshops were planned to further engage the youth and advance philanthropic skills.

In the first workshop following the retreat, the Spartanburg County Foundation (SCF) introduced fund raising methods and ways to raise a match. The youth chose to write a letter describing the project and asking for financial support. The SCF conducted an additional instructional workshop in writing the solicitation letter. The youth wrote the letter, formed three solicitation teams and developed a list of prospects to receive the letters. In subsequent meetings, letters were mailed and followed with a personal phone call.

A University communications specialist instructed the youth in how to plan a press conference and write a press release. Following this activity they held a press conference with the local newspaper to announce the project. They met with a USC Upstate grant writer for a workshop on writing a request for proposals and made an announcement for proposals at a Youth Council Meeting. The grant writing conducted a follow-up session to develop a scoring protocol to evaluate the proposals. The solicitation letter was successful and the youth raised the required match of $\$ 4000$, bringing the total amount the youth would award to $\$ 12,000$. The youth wrote personal thank you notes to all donors.

The youth met to review the proposals that were received from local non-profits. After evaluating each application individually using the scoring criteria they created, (See Appendix A) they worked as a team to determine the grant amounts. Grant proposals were received from nine organizations totaling $\$ 14,644$. The youth approved all nine applications and awarded $\$ 12,000$ to these organizations thereby funding at least a portion of each one.

\section{Results and Conclusion}

A final meeting was scheduled to discuss the philanthropy project and assess the outcomes of the project. Eighteen youth attended the meeting and completed the Youth Experience Survey 2.0 (Hansen, D. M. \& Larson, R., 2002). The Youth Experience Survey (YES) is a questionnaire designed to assess high-school students' developmental experiences in an extracurricular activity or community-based program. The questionnaire, designed for use with multiethnic youth, assesses self-reported experiences in the activity or program in the following six areas of development: Identity Work, Initiative, Basic Skills, Teamwork and Social Skills, Interpersonal Relationships, and Adult Networks.

When youth are viewed as community assets and given opportunities to become involved in their community, positive development is the result. Research indicates that youth are active participants in their own development and we believe they are also accurate self-reporters of their developmental experiences. Given the research indicating a decline in civic engagement (Putnam, 2000), and evidence that this decline can be addressed, we believe that scholars and community leaders should pursue initiatives to foster civic skill building and engage youth in 
their communities. When we teach youth about philanthropy and fundraising we are not only building future philanthropists, but also empowering youth to see themselves as leaders and agents of change. Universities are uniquely equipped with resources that can promote youth engagement in communities.

The young philanthropists reported positive developmental experiences in identity formation, initiative, interpersonal ability, teamwork and adult networks. Table 1 presents the positive developmental experiences reported by the youth participants. These young people not only increased their awareness of needs in the community and their level of responsibility to their community but also developed a sense of place in their community. While this is a small sample, the results are overwhelmingly positive and suggest that leadership programs should consider this model. The following paragraph is quoted from a participant one year later.

It had an impact on the community and it had an impact on me because a lot of local issues were brought up in the project that I was I naïve to-I didn't know they existed. I went from a minute involvement in the community to being highly involved. The project helped me build relationships with community leaders such as the Mayor and people you don't meet on an every day basis-but in this project, I got to know them and work with them. It changed my relationship with my peers in that the philanthropy group included people from different schools, backgrounds, and people I wouldn't have ordinarily met or meshed with. It helps me now to be able to work with people of diverse backgrounds because not everyone is the same. I'm very motivated to continue with this type of work. I've grown to enjoy and actually love community service.

From a developmental perspective, adolescence is an optimal time to learn skills that facilitate civic engagement. At this stage of personal and social development, youth are actively engaged in the process of identity exploration and formulating a cohesive identity, which involves a deeper understanding of self, social relationships and society, and deciding which values held by society, will be accepted as one's own (Erikson, 1968). Developmental psychologists in recent decades have moved from a focus on individual growth to an emphasis on the contextual influences on development (Bronfenbrenner, 1979). Thus civic involvement becomes an important context for consolidating an identity that includes political/civic development. The inclusion of civic engagement in youth programs incorporates greater social responsibility and political values into the identity process and contributes to positive social relationships (Flanagan, 2003).

None of the youth that participated could explain philanthropy in the beginning of the project or name an important issue facing the community. However, at the conclusion, all youth understood the concept and indicated a commitment to future philanthropic involvement. Additionally the youth became more aware and involved in their community and formed meaningful relationships with adult community leaders. 
Table 1

Youth Experience Survey 2.0 (YES)

Developmental Experiences $\mathrm{N}=18$

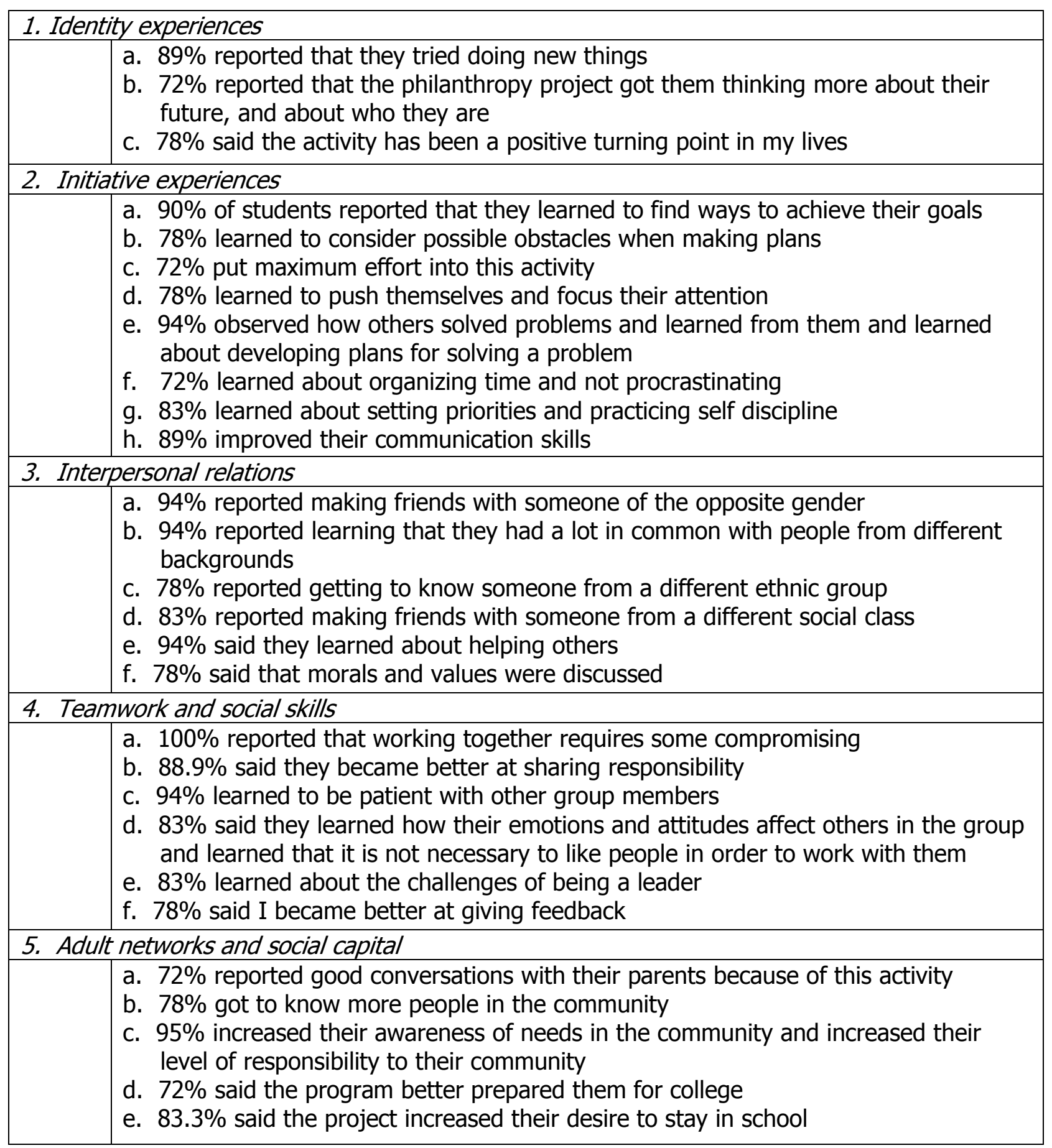

Acknowledgement:

The Mary Black Foundation

The Spartanburg County Foundation

Spartanburg Regional Healthcare Foundation

The United Way of the Piedmont

Citizens of Spartanburg, SC 


\section{References}

Bronfenbrenner, U. (1979). The ecology of human development: Experiments by nature and design. Cambridge, MA: Harvard University Press.

Dworkin, J.B., Larson, R., \& Hansen, D. (2003). Adolescents' accounts of growth experiences in youth activities. Journal of Youth and Adolescence, 32, 17-26.

Erickson, E.H. (1968). Identity: Youth and crisis. New York: W.W. Norton.

Evans, S.D. \& Prilleltensky, I. (2007). Youth and democracy: Participation for personal, relational, and collective well-being. Journal of Community Psychology, 35(6), 681-692.

Flanagan, C. (April 2003). Developmental roots of political engagement. PS: Political Science \& Politics. 36(2), 257-261.

Hansen, D.M., \& Larson, R. (2002). The Youth Experience Survey. Unpublished manuscript. University of Illinois at Urbana-Champaign.

Hansen, D.M., Reed, L.W., \& Dworkin, J.B. (2003). What adolescents learn in organized youth activities: A survey of self-reported developmental experiences. Journal of Research on Adolescence, 13(1), 25-55.

Harré, N. (2007). Community service or activism as an identity project for youth. Journal of Community Psychology, 35(6), 711-724.

Jarrett, R.L., Sullivan, P.J., \& Watkins, N.D. (2005). Developing social capital through participation in organized youth programs: Qualitative insights from three programs. Journal of Community Psychology, 33(1), 41-55.

Larson, R.W. (2000). Toward a psychology of positive youth development. American Psychologist, $55(1), 170-183$.

Libby, M., Rosen, M., \& Sedonaen, M. (2005). Building youth-adult partnerships for community change: Lessons from the youth leadership institute. Journal of Community Psychology, 33(1),111-120.

Mannheim, K. (1952). "The problem of generations." In Essays in the Sociology of Knowledge. Trans. and ed. Paul Kecskemeti. New York: Oxford Press, 276-322.

Putnam, R.D. (2000). Bowling alone: The collapse and revival of American community. New York: Simon \& Schuster.

Watts, R.J., \& Flanagan, C. (2007). Pushing the envelope on youth civic engagement: A developmental and liberation psychology perspective. Journal of Community Psychology, 35(6), 779-792.

Yates, M., \& Youniss, J. (1996). Community service and political-moral identity in adolescents. Journal of Research on Adolescence, 6(3),271-284.

(C) Copyright of Journal of Youth Development $~$ Bridging Research and Practice. Content may not be copied or emailed to multiple sites or posted to a listserv without copyright holder's express written permission. However, users may print, download or email articles for individual use. 


\section{Appendix A}

RFP Review Sheet

\section{First Review}

Checklist

(Applications must meet all of the following criteria to continue to the second review)

- Maximum of 2 pages

- 12 point type

- 1 inch margins

- $501 \mathrm{c} 3$ letter

- Budget does not request salary or travel funds

- Letter from program participant

- Met the 3/12, 5:00 PM deadline

\section{Second Review}

\section{Scoring}

MISSION

Is the applicant's mission a good fit for Youth Philanthropy Goal?

PAST ACCOMPLISHMENTS (10)

Has the applicant proven a record of success with similar projects?

PURPOSE

Is the proposed project important to Spartanburg?

NEED (10)

Does Spartanburg need the proposed project?

OBJECTIVES (25)

Has the applicant clearly detailed what they will achieve and how they'll achieve it?

EVALUATION (10)

Has the applicant fully explained how they will know if the project is a success?

BUDGET (5)

Is the amount requested reasonable? Is it clear what the money will be used for?

TOTAL SCORE $(100)$ Application Summary: 


\section{Appendix B \\ The Youth Experiences Survey (YES) 2.0}

Instructions: Based on your recent involvement please rate whether you have had the following experiences in the Youth and Philanthropy project.

\section{IDENTITY EXPERIENCES}

\begin{tabular}{|c|c|c|c|}
\hline \multicolumn{4}{|c|}{ Your Experiences In...... } \\
\hline \begin{tabular}{|c|c|}
\hline Youth and Philanthropy Project \\
\hline Yes, \\
Definitely
\end{tabular} & $\begin{array}{c}\text { Quite a } \\
\text { Bit }\end{array}$ & A Little & $\begin{array}{c}\text { Not At } \\
\text { All }\end{array}$ \\
\hline
\end{tabular}

\section{Identity Exploration}

1. Tried doing new things

2. Tried a new way of acting around people

3. I do things here I don't get to do anywhere else

\begin{tabular}{|l|l|l|l|}
\hline 1 & 2 & 3 & 4 \\
\hline 1 & 2 & 3 & 4 \\
\hline 1 & 2 & 3 & 4 \\
\hline
\end{tabular}

\section{Identity Reflection}

4. Started thinking more about my future because of this activity

5. This activity got me thinking about who I am

6. This activity has been a positive turning point in my life

\begin{tabular}{|l|l|l|l|}
\hline 1 & 2 & 3 & 4 \\
\hline 1 & 2 & 3 & 4 \\
\hline 1 & 2 & 3 & 4 \\
\hline
\end{tabular}

\section{INITIATIVE EXPERIENCES}

\section{Goal Setting}

7. I set goals for myself in this activity

8. Learned to find ways to achieve my goals

9. Learned to consider possible obstacles when making plans

\begin{tabular}{|l|l|l|l|}
\hline 1 & 2 & 3 & 4 \\
\hline 1 & 2 & 3 & 4 \\
\hline 1 & 2 & 3 & 4 \\
\hline
\end{tabular}

\section{Effort}

10. I put all my energy into this activity

11. Learned to push myself

12. Learned to focus my attention

\begin{tabular}{|l|l|l|l|}
\hline 1 & 2 & 3 & 4 \\
\hline 1 & 2 & 3 & 4 \\
\hline 1 & 2 & 3 & 4 \\
\hline
\end{tabular}

\section{Problem Solving}

13. Observed how others solved problems and learned from them

14. Learned about developing plans for solving a problem

15. Used my imagination to solve a problem

\begin{tabular}{|l|l|l|l|}
\hline 1 & 2 & 3 & 4 \\
\hline 1 & 2 & 3 & 4 \\
\hline 1 & 2 & 3 & 4 \\
\hline
\end{tabular}

\section{Time Management}

16. Learned about organizing time and not procrastinating (not putting things off)

17. Learned about setting priorities

18. Practiced self discipline

\begin{tabular}{|l|l|l|l|}
\hline 1 & 2 & 3 & 4 \\
\hline 1 & 2 & 3 & 4 \\
\hline 1 & 2 & 3 & 4 \\
\hline
\end{tabular}

